\title{
Strength and Durability Properties of Concrete Containing Pumice and Scoria as Supplementary Cementitious Material
}

\author{
Safiel Tumaini Chambua $\mathbb{D}^{1,2}$ Yusufu Abeid Chande Jande ${ }^{1 D},{ }^{1,2}$ \\ and Revocatus Lazaro Machunda $\mathbb{i D}^{2,3}$ \\ ${ }^{1}$ Department of Materials and Energy Sciences and Engineering, \\ The Nelson Mandela African Institution of Science and Technology, P.O. Box 447, Arusha, Tanzania \\ ${ }^{2}$ Water Infrastructure and Sustainable Energy Futures, The Nelson Mandela African Institution of Science and Technology, \\ P.O. Box 9124, Arusha, Tanzania \\ ${ }^{3}$ Department of Water and Environmental Science and Engineering, \\ The Nelson Mandela African Institution of Science and Technology, P.O. Box 447, Arusha, Tanzania
}

Correspondence should be addressed to Safiel Tumaini Chambua; chambuas@nm-aist.ac.tz

Received 28 February 2021; Revised 28 March 2021; Accepted 9 April 2021; Published 24 April 2021

Academic Editor: Zbyšek Pavlík

Copyright (c) 2021 Safiel Tumaini Chambua et al. This is an open access article distributed under the Creative Commons Attribution License, which permits unrestricted use, distribution, and reproduction in any medium, provided the original work is properly cited.

\begin{abstract}
Concrete structures suffer serious deterioration under a corrosive environment. Consequently, the service life of these concrete structures is decreased and deteriorates under combined attack of sulphate and chlorides. Most studies confined on single deteriorating factor such as sulphate attack only or chloride attack only but the current study focused on the influence of natural pumice (NP) and natural scoria (NS) on the strength performance of concrete exposed to the combined attack of sulphate and chloride. Portland cement (PLC) was replaced with NP or NS at a substitution level of $10 \%$. Concrete samples were cured in water for the curing period of 28 days. Afterwards, the specimens were immersed in $5 \%$ sodium sulphate $\left(\mathrm{Na}_{2} \mathrm{SO}_{4}\right), 5 \%$ sodium chloride $(\mathrm{NaCl})$, and combined sodium sulphate and chloride solutions for additional curing of 28, 56, and 90 days. The results were compared between concrete mixes with NP or NS and control mix (CT) with PLC. The effects of sulphate, chloride, and combined sulphate and chloride were evaluated in terms of change in weight, variation in compressive strength, and degree of damage. Conclusively, the application of NP and NS has extraordinary potential to be utilized as a cementitious material in concrete to increase the resistance against aggressive salts.
\end{abstract}

\section{Introduction}

Concrete has been a dominant construction material for the infrastructure around the globe [1]. It is estimated that the global production is over 10000 million tons [2]. The development in concrete technology has led the material to be the choice for the construction of structures which are exposed to extreme conditions [3]. Despite concrete being the chief construction material, the concrete structures made with Ordinary Portland cement (OPC) tend to depreciate faster when exposed to extreme conditions.

Structures exposed to extreme conditions are such as waste water treatment plants and marine structures [4].
Researchers have studied the durability of concrete under different extreme conditions [5-10]. It was singled out that sulphate, chloride, and their associated cations are the most aggressive chemicals affecting concrete durability. The concrete durability becomes a major concern since the capacity to withstand imposed load decreases with time. Moreover, the cost of repair and replacement of deteriorated structures becomes astronomical $[11,12]$.

Nowadays, there is prevailing interest to reduce the cement content and enhance concrete strength and durability by using Supplementary Cementing Materials (SCMs) and make more durable and sustainable concrete with good structural properties $[13,14]$. The properties of fresh and 
hardened concrete are improved by addition of SCMs, and the cement content is reduced simultaneously [13]. Downrightly, the SCMs' addition improves workability and flow [13], produces less porous and denser concrete which increase resistance to chemical attack [15], shock absorbing ability is enhanced $[16,17]$, and compressive and flexural strengths are enhanced [13].

Furthermore, SCMs produce the additional Calciumsilicate-hydrate $(\mathrm{C}-\mathrm{S}-\mathrm{H})$ gel from the pozzolanic reaction between the calcium hydroxide $(\mathrm{C}-\mathrm{H})$ that forms from the cement hydration [13]. The C-S-H gel together with the packing effect of fine and coarse aggregate increases compatibility of concrete, thus reducing permeability and protection of steel reinforcement against corrosion $[18,19]$. Different research studies have been investigating the concrete with SCMs immersed in the sulphate and chloride environment as follows.

Kannan and Ganesan [20] investigated the chemical and chloride resistance of self-compacting concrete incorporated with rice husk and metakaolin and declared that concrete incorporated with metakaolin and rice husk leads to improvement in the strength and reducing permeability when compared to the control mix.

Mangi et al. [1] investigated the effects of sodium and chloride attack on concrete blended with coal bottom ashes for the exposure period of 90 days, and it was found that incorporation of coal bottom ashes reduces the negative effects of sulphate and chloride salts and increases the concrete resistance against the aggressive environment.

Aksogan et al. [14] investigated the durability performance of concrete where the fine aggregate was replaced by calemanite and barite and cement by corn stalk, wheat straw, and sunflower stalk ashes immersed in $5 \% \mathrm{Na}_{2} \mathrm{SO}_{4}$ for 180 days and stated that, upon addition of corn stalk, wheat straw, and sunflower stalk ashes, the chemical resistance of concrete was improved.

Demir et al. [21] replaced cement with the combination of fly ash, bottom ashes, and blast-furnace slag and evaluated the performance of Ordinary Portland Cement (OPC) mortars under $5 \% \mathrm{Na}_{2} \mathrm{SO}_{4}$ solution for 360 days. It was found the blended cement mortar has a compressive strength of $2 \%$ greater than that of OPC when cement is replaced with $5 \%$ fly ash, $5 \%$ blast-furnace slag, and 5\% bottom ash.

Othman et al. [22] investigated the sulphate resistance of foamed concrete containing processed spent bleaching earth (PSBE) as the cement replacement. The sulphate resistance was evaluated in terms of expansion, loss in mass, and loss in compressive strength after 52 weeks of immersion time. It was found that concrete containing $30 \%$ PSBE is more durable than the control specimen after immersion in $5 \%$ sodium sulphate. However, the investigation was based on single attack only.

Al-Swaidani and Aliyan [7] investigated the sulphate resistance of mortars by partially replacing cement with scoria. The sulphate resistance of mortars was performed by immersing the mortar samples in 5\% Na2SO4 solution for 52 weeks and declared that, upon addition of scoria, the sulphate resistance of mortars is improved. The investigation was done only on single deteriorating factor, that is, sulphate attack only.

Jaya et al. [23] investigated the potential of using rice husk ashes (RHA) as the cement replacement in concrete under seawater attack by wetting and drying cycles. Cement was replaced with RHA at the substitution level of $0 \%, 10 \%$, $20 \%, 30 \%$, and $40 \%$. Compressive strength and chloride ion permeability were evaluated. Incorporation of RHA was found to reduce calcium hydroxide formation during hydration seawater attack. The investigation was based on single attack only.

Natural pumice (NP) and natural scoria (NS) are natural materials that can be used as eco-friendly materials in the construction industry. Cement production requires energy, and much $\mathrm{CO}_{2}$ is released but utilization of NS and NS reduces energy demand and $\mathrm{CO}_{2}[13,24]$. NP and NS are pyroclastic materials rich in silica, alumina, and iron oxide [24]. Around the globe, NP and NS have been utilized as fine and coarse aggregates in concrete production and building blocks [13]. Top and Vapur investigated the utility of NP as course aggregates in light-weight geopolymer concrete [25]. Then again, NP and NS have been used as fine and coarse aggregates for nonstructural concrete and mortar [17, 26, 27].

Mboya et al. [13] indicated that NP and NS as the cement replacement can enhance the strength and durability of concrete but studies on concrete containing NP and NS under the combined exposure of sulphate and chloride are rarely reported. In addition, no research has evaluated the properties of concrete NP and NS under the combined exposure of sulphate and chloride solutions. Moreover, the earlier inputs by Mboya et al. [13] validated that the compressive strength of concrete incorporated with NP and NS was satisfactory at a $10 \%$ substitution level. The $10 \%$ substitution level of cement with NP and NS has been adopted. Therefore, the work presented explores the application of NP and NS as SCMs in concrete under the combined effect of sulphate and chloride solution exposure conditions. Strength, change in weight, and degree of damage are evaluated.

\section{Materials and Methods}

\subsection{Materials}

2.1.1. Binder. In the current study, Portland Limestone Cement (PLC) type II (Twiga plus) class $42.5 \mathrm{~N}$ conforming to Tanzanian standard TZS727:2002 in accordance with the British standard BS 12:1996 13 and SS-EN 197-1 CEM II/A-L was used [28]. PLC was obtained from local dealers around Arusha city, Tanzania.

Pumice stone with white colored fragments was collected from Ikuti in Mbeya region, and scoria stone with red colored fragments was collected from Uchira in Kilimanjaro region. Both were collected in Tanzania. A disc mill model 4A100L6T1 SN 535277 was used to mill pumice and scoria stones to produce a fine powder of pumice and scoria marked NP and NS, respectively, at a rate of $2 \mathrm{~kg} / \mathrm{h}$ and sieved through $75 \mu \mathrm{m}$ in accordance with BS 410 [29], visually presented in Figure 1, and analyzed to determine 


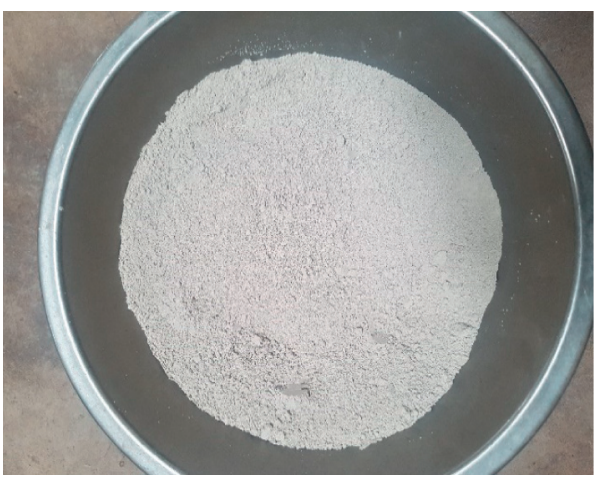

(a)

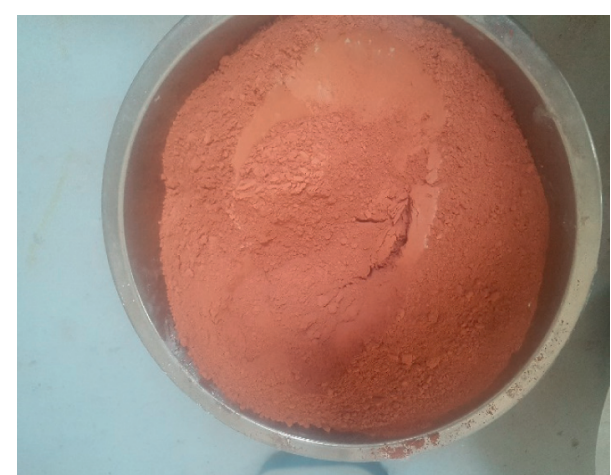

(b)

Figure 1: Pumice and scoria powder used in the study.

chemical and physical properties. Automatic Blaine Apparatus (AIM-391-3) SN 2001 from Aimil Ltd., India was used to determine fineness of the NP and NS powder [30]. The density of PLC, NP, and NS was determined according to SSEN 197-1 and ASTM D 854 [31, 32]. The chemical and physical properties of binders are outlined under the result section.

2.1.2. Aggregates. Fine and coarse aggregates were obtained from local dealers. Properties of fine and coarse aggregates such as specific gravity and water absorption were determined, guided by the standard. ASTM C127 [33] and ASTM C128 [34] were employed to determine aforementioned properties, respectively. Particle size requirement for aggregates was done to conform to BS EN 933-1:2012 [35]. Grading and blending of fine and coarse aggregates were done to conform with PD 6682-1 and BS 12620 specifications [36, 37].

The particle size distribution and properties of fine and coarse aggregates used in the study are shown in Figure 2 and Table 1, respectively. To achieve desired properties of fresh and hardened concrete, fine and coarse aggregates were graded and blended together to obtain the right proportions [36]. BS EN 12620 was used to blend coarse and fine aggregates in proportions of $33 \%$ to $67 \%$ fine to coarse aggregates [36]. The blended aggregates showed fineness modulus (FM) of 5.1 and specific gravity (SG) of 2.6. The specific gravity of aggregates was found to be between 2.4 and 2.8 which suggest that the aggregates used were normal weight aggregates [13].

2.1.3. Water. Potable tap water was used for washing aggregates and mixing and curing of concrete. Water used was free from suspended particles, and the $\mathrm{pH}$ value was 6 . The amount of water added during mixing reacts with cement to form the hydration products which bind the aggregates together, which also affect the workability of the concrete and strength properties. Mixing water was free from chemical contamination and safe for human consumption [38].

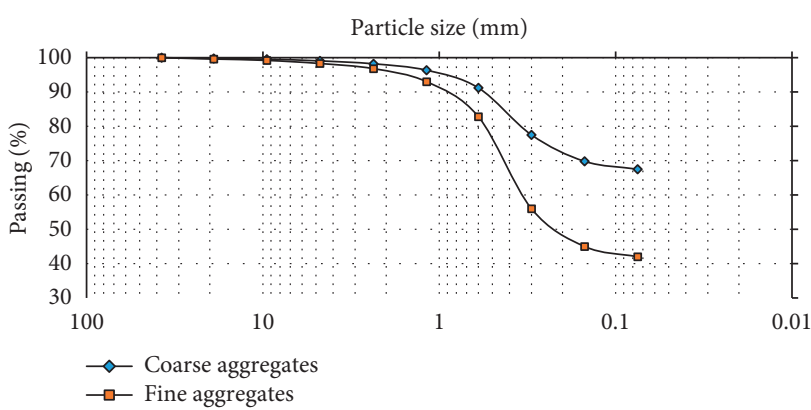

FIgURE 2: The particle size distribution of aggregates used in the study.

2.2. Mix Proportioning. Concrete grade M25 was adopted in this study, and the concrete samples were made by partially replacing cement with NP or NS. BS 1881-116 [39], BS EN 12390-2 [40], and BS EN 206 [41] were used as guidelines for concrete mixing, casting, and testing of fresh and hardened properties of concrete, respectively. Three streams of test specimens were under consideration; the first stream was the concrete made with only Portland cement ( $0 \%$ replacement) (hereafter, referred as CT), the second stream was the concrete made with partial replacement of cement by NP, and the third stream was the concrete made with partial replacement of cement with NS. Cement was replaced by $10 \%$ in second and third streams, as illustrated in Table 2.

2.3. Sample Preparation. Concrete mixes were prepared by using an electric mixer. The weighed PLC and fine and coarse aggregates were all together put into the concrete mixer and mixed thorough, followed by addition of NP and NS and mixed through. Weighed water was added and mixed throughout to have a homogeneous mixture. Standard cubes of $150 \mathrm{~mm}$ size were used to prepare concrete cubes with and without NP and NS. A total of 108 specimens were prepared, and three cubes from each stream were selected for testing in the corrosive environment. Concrete specimens were left to allow setting at a room temperature of $25 \pm 3^{\circ} \mathrm{C}$ after casting. The 
TABle 1: Properties of aggregates used in the study.

\begin{tabular}{lcc}
\hline Properties & Coarse aggregates & Fine aggregates \\
\hline Maximum size $(\mathrm{mm})$ & 20 & 4.75 \\
Water absorption $(\%)$ & 0.8 & 1.3 \\
Specific gravity & 2.96 & 2.65 \\
Bulk density $\left(\mathrm{kg} / \mathrm{m}^{3}\right)$ & 2956 & 2649 \\
Moisture content $(\%)$ & 3.5 & 4.57 \\
Fineness modulus & 6.6 & 2.2 \\
\hline
\end{tabular}

TABle 2: Concrete mix design.

\begin{tabular}{lcc}
\hline & \multicolumn{2}{c}{$\begin{array}{c}\text { Percent of PLC } \\
\text { Components }\left(\mathrm{kg} / \mathrm{m}^{3}\right)\end{array}$} \\
& 0 & 10 \\
\hline Cement & 380 & 342 \\
$\mathrm{NP} / \mathrm{NS}$ & 0 & 38 \\
Fine aggregate & 552 & 552 \\
Coarse aggregate & 1243 & 1243 \\
Water & 205 & 205 \\
\hline
\end{tabular}

demoulding of cubes was done after $24 \mathrm{~h}$, and then, the specimens were cured in water for 7 and 28 days to obtain the designed strength. Specimens were taken out of the water tank after 7 and 28 days and left out for $24 \mathrm{~h}$ to allow drying under controlled laboratory conditions. Compaction and curing equipment used complied with BS EN $12390-2$ [40] and BS 1881-116 [39].

2.4. Continuous Immersion Test. A methodology similar to earlier studies $[1,4]$ was adopted, where 9 specimens of CT, 9 specimens of $\mathrm{S} 1$, and 9 specimens of $\mathrm{S} 2$ were immersed in 5\% $\mathrm{Na}_{2} \mathrm{SO}_{4}, 5 \% \mathrm{NaCl}$, and combination $5 \% \mathrm{Na}_{2} \mathrm{SO}_{4}$ and $5 \%$ $\mathrm{NaCl}$ for 28, 56, and 90 days, respectively. The remaining specimens were submerged in water for additional curing of 28,56 , and 90 days.

2.5. Testing. The CT specimens were weighed and tested without immersing them into the corrosive environment. Before submerging concrete mixes in the corrosive environment, all specimens were weighed. After the continuous immersion test of samples in the corrosive environment, the samples were weighed again. The mass loss was assessed by using the recorded weights at each exposure condition. The compressive strength testing machine conforming to BS EN 12390-2 [40] and BS 1881-116 [39] was used to measure the strength of concrete samples. The crushing loads were obtained in accordance with BS EN 12390-3:2019 [42]. Their degree of damage was evaluated by using equation (1) as described by Mangi et al. [1]:

$$
D_{i}=1-\frac{\sigma_{i}}{\sigma_{0}},
$$

where $D_{i}$ is the degree of damage after certain immersing period, $\sigma_{i}$ is the compressive strength of concrete after certain immersing time, and $\sigma_{0}$ is the initial compressive strength of concrete. In the current study, the $\sigma_{0}$ value represents the compressive strength of CT, S1, and S2 at the age of 28 days before being shifted into sulphate and chloride solutions.

\section{Results and Discussion}

3.1. Physical and Chemical Properties of PLC, NP, and NS. $X$-ray Fluorescence (XRF) was used to analyze chemical composition of PLC, NP, and NS. The results are presented in Table 3. The total of silica, aluminum oxide, and iron oxide was found to be $74.76 \%$ and $67.34 \%$ for NP and NS, respectively. This implies that NS and NP meet the standard criteria to be considered as pozzolanic materials according to ASTM C618 [43]. Physical properties of PLC, NP, and NS are presented in Table 4.

3.2. Workability. Slump cone method was used to evaluate the workability of concrete with accordance to ASTM C143 [44]. Workability results of the concrete mix CT (control mix), S1 (concrete containing NP), and S2 (concrete containing NS) are shown in Table 5. The slump results reveal that slump decreases with increase of cement replacement, and this is due to the presence of NP and NS which upon their addition, increases silicon concentration which increases water demand in order to produce workable concrete [45]. This result was also observed by Mboya et al. [13] and Adesanya and Raheem [45] when SCMs were used as partial substitution of cement in concrete production.

3.3. Weight Loss. The weight of the concrete specimen was taken before and after immersing the specimen in water, sulphate, chloride, and combination of sulphate and chloride solution. The detailed results of mass loss are provided in Figure 3. The result reveals that both types of concrete do not change their weight when immersed in water. The significant change in weight is noted when both types of specimens are immersed in $5 \% \mathrm{Na}_{2} \mathrm{SO}_{4}, 5 \% \mathrm{NaCl}$, and the combination of both. The highest weight loss was noticed in $\mathrm{CT}$ at 56 days, while the lowest was observed in both $\mathrm{S} 1$ and S2 when exposed to $5 \% \mathrm{Na}_{2} \mathrm{SO}_{4}$. Concrete with NP and NS has lower values compared to the control mix because of the denser structure which reduces salts' penetration.

It was also agreed by Xu et al. [46] that higher amounts of sulphate ions, gypsum, and ettringite are influenced by more hydration products which provide growth in weight of the specimen containing $30 \%$ fly ash in $5 \% \mathrm{Na}_{2} \mathrm{SO}_{4}$ [1]. Under combined sulphate and chloride, there is significant mass loss from 28 days up to 90 days, and CT concrete is more affected, and this is mainly attributed by formation of more ettringite and gypsum. This concurs with the findings of Maes and De Belie [47] where the investigation was performed to evaluate the effect of combined attack of chloride and sulphate on concrete and mortar.

Incorporation of NP and NS reduces the hydration process; moreover, it reduces the penetration of salt in concrete, thus no significant loss in weight in S1 and S2. This assures that incorporation of SCMs in concrete (S1 and S2) could reduce the permeability of corrosive species which cause corrosion in reinforced structures and failure of 
TABle 3: Chemical properties of PLC, NP, and NS.

\begin{tabular}{lccc}
\hline Chemical properties & \multicolumn{3}{c}{ Material } \\
& PLC & NP & NS \\
\hline $\mathrm{SiO}_{2}$ & 17.9 & 55.91 & 39.07 \\
$\mathrm{CaO}$ & 60.9 & 0.52 & 10.32 \\
$\mathrm{Al}_{2} \mathrm{O}_{3}$ & 5.5 & 14.55 & 12.80 \\
$\mathrm{Fe}_{2} \mathrm{O}_{3}$ & 2.9 & 4.30 & 15.47 \\
$\mathrm{MgO}$ & 0.5 & 0.21 & 4.82 \\
$\mathrm{TiO}_{2}$ & - & 0.55 & 3.84 \\
$\mathrm{~K}_{2} \mathrm{O}$ & 0.22 & 5.01 & 0.62 \\
$\mathrm{MnO}$ & 0.36 & 0.36 & 0.22 \\
$\mathrm{Na}$ & - & 4.95 & 0.40 \\
Loss on ignition & 8.4 & 8.79 & 10.73 \\
\hline
\end{tabular}

TABle 4: Physical properties of PLC, NP, and NS.

\begin{tabular}{lccc}
\hline Physical properties & \multicolumn{3}{c}{ Material } \\
& PLC & NP & NS \\
\hline Density $\left(\mathrm{kg} / \mathrm{m}^{3}\right)$ & 3010 & 2390 & 2930 \\
Blaine-specific surface area $\left(\mathrm{m}^{2} / \mathrm{kg}\right)$ & 431 & 507 & 575 \\
Initial setting time (minutes) & 148 & - & - \\
Soundness $(\mathrm{mm})$ & 1.5 & - & - \\
Compressive strength 28 days $(\mathrm{MPa})$ & 45 & - & - \\
\hline
\end{tabular}

TABle 5: Concrete workability.

\begin{tabular}{lc}
\hline Concrete mix & Slump value $(\mathrm{mm})$ \\
\hline Control mix (CT) & 68 \\
Concrete with 10\% NP (S1) & 60 \\
Concrete with 10\% NS (S2) & 60
\end{tabular}

structure $[48,49]$. Thus suggesting that incorporation of NP and NS prohibits penetration of aggressive salts making concrete adequate under $5 \% \mathrm{NaCl}$ and $5 \% \mathrm{Na}_{2} \mathrm{SO}_{4}$ and combination of both $5 \% \mathrm{NaCl}$ and $5 \% \mathrm{Na}_{2} \mathrm{SO}_{4}$.

3.4. Compressive Strength Variation. The strength comparison between concrete with natural pumice (S1) and concrete with natural scoria (S2) with reference to CT (concrete without natural pumice and scoria) under different exposure conditions at the age of 28,56 , and 90 days was used to assess the variation in compressive strength. At the early age of 28 days, the increase in compressive strength was slow for S1 (concrete containing NP) and S2 (concrete containing NS) when immersed in $5 \% \mathrm{Na}_{2} \mathrm{SO}_{4}$ solution but significant increase in compressive strength is noticeable at the age of 56 and 90 days.

The concrete samples S1 (concrete containing NP) and S2 (concrete containing NS) under $5 \% \mathrm{NaCl}$ have significant reduction of strength. Moreover, similar observation is noticed in concrete specimens exposed in the combined 5\% $\mathrm{Na}_{2} \mathrm{SO}_{4}$ and $\mathrm{NaCl}$ solution. The performance of concrete was superior under water and $\mathrm{Na}_{2} \mathrm{SO}_{4}$ solution. Concrete containing pumice (S1) has $12.11 \%$ and $9.9 \%$ higher strength than the control mix (CT) in water and in $5 \% \mathrm{Na}_{2} \mathrm{SO}_{4}$ solution, respectively, at the age 56 days, and concrete

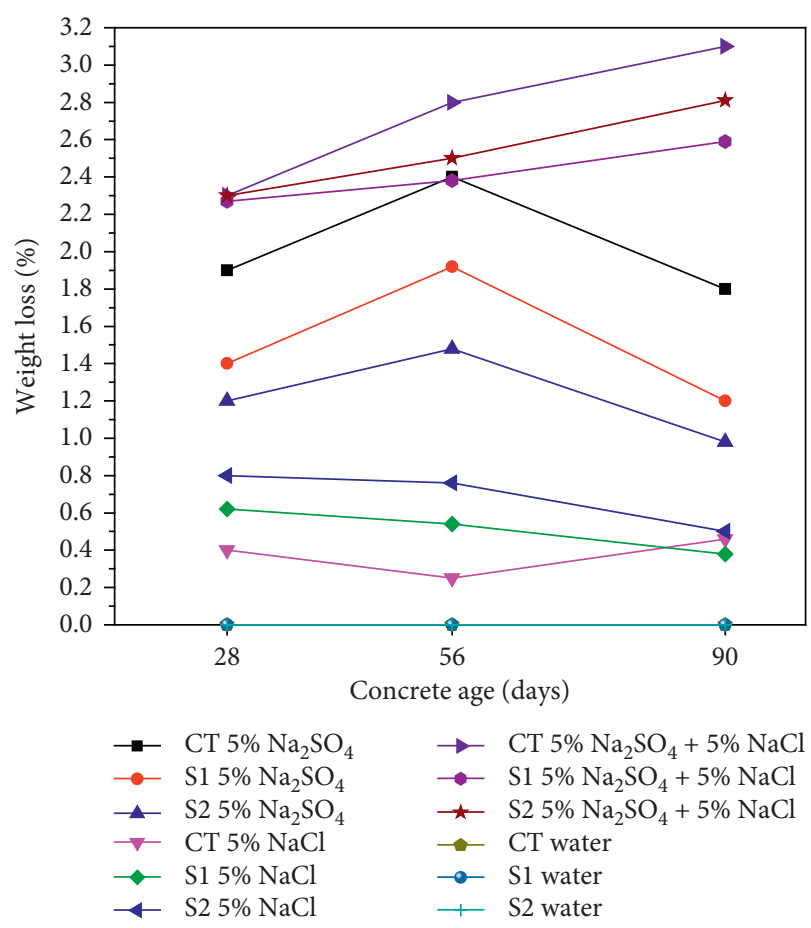

FIGURE 3: Weight loss of CT, S1, and S2 immersed in sulphate, chloride, and combined sulphate and chloride solution.

containing scoria (S2) has $6.3 \%$ and $4.6 \%$ higher strength than the control mix (CT) in water and $5 \% \mathrm{Na}_{2} \mathrm{SO}_{4}$ solution, respectively, at the age of 56 days. For 90 days cured samples, concrete containing pumice has $7.7 \%$ and $15.4 \%$ in water and $5 \% \mathrm{Na}_{2} \mathrm{SO}_{4}$ solution, respectively, while concrete containing scoria has $3.04 \%$ and $13.6 \%$ in water and $5 \% \mathrm{Na}_{2} \mathrm{SO}_{4}$ solution, respectively.

The concrete containing pumice (S1) and scoria (S2) showed the drop of strength under $5 \% \mathrm{NaCl}$ exposure condition. Under the combination of both $5 \% \mathrm{Na}_{2} \mathrm{SO}_{4}$ and $\mathrm{NaCl}$ solution, concrete containing pumice has $8 \%$ and concrete containing scoria has $7.3 \%$ higher strength than the control mix (CT) at the age of 90 days. Figure 4 demonstrates the differential in compressive of concrete specimens $\mathrm{S} 1$ and $\mathrm{S} 2$ under $\mathrm{Na}_{2} \mathrm{SO}_{4}$ and $\mathrm{NaCl}$ solutions at different concrete ages.

3.5. Compressive Strength of the Specimens under Water, Sulphate, and Chloride Solutions. The compressive strength for the dried samples was determined after the immersion test. The compressive strength of 28,56 , and 90 days immersed samples in potable water is presented in Figure 5. The results demonstrate that the performance of concrete samples S1 (34.3 MPa) and S2 (33.4) is higher than the CT $(31.9 \mathrm{MPa})$ at 28 days when immersed in water; this indicates that the pozzolanic reaction initiated the growth of strength in concrete samples $\mathrm{S} 1$ and $\mathrm{S} 2$. For instance, the compressive strength of $\mathrm{S} 1$ is higher by $12.11 \%$ and $7.7 \%$ as compared to $\mathrm{CT}$ at 56 and 90 days, respectively. S2 compressive strength is higher by $6.3 \%$ and $3.04 \%$ as compared to CT at 56 and 90 days, respectively. It was noted that, under the presence of 


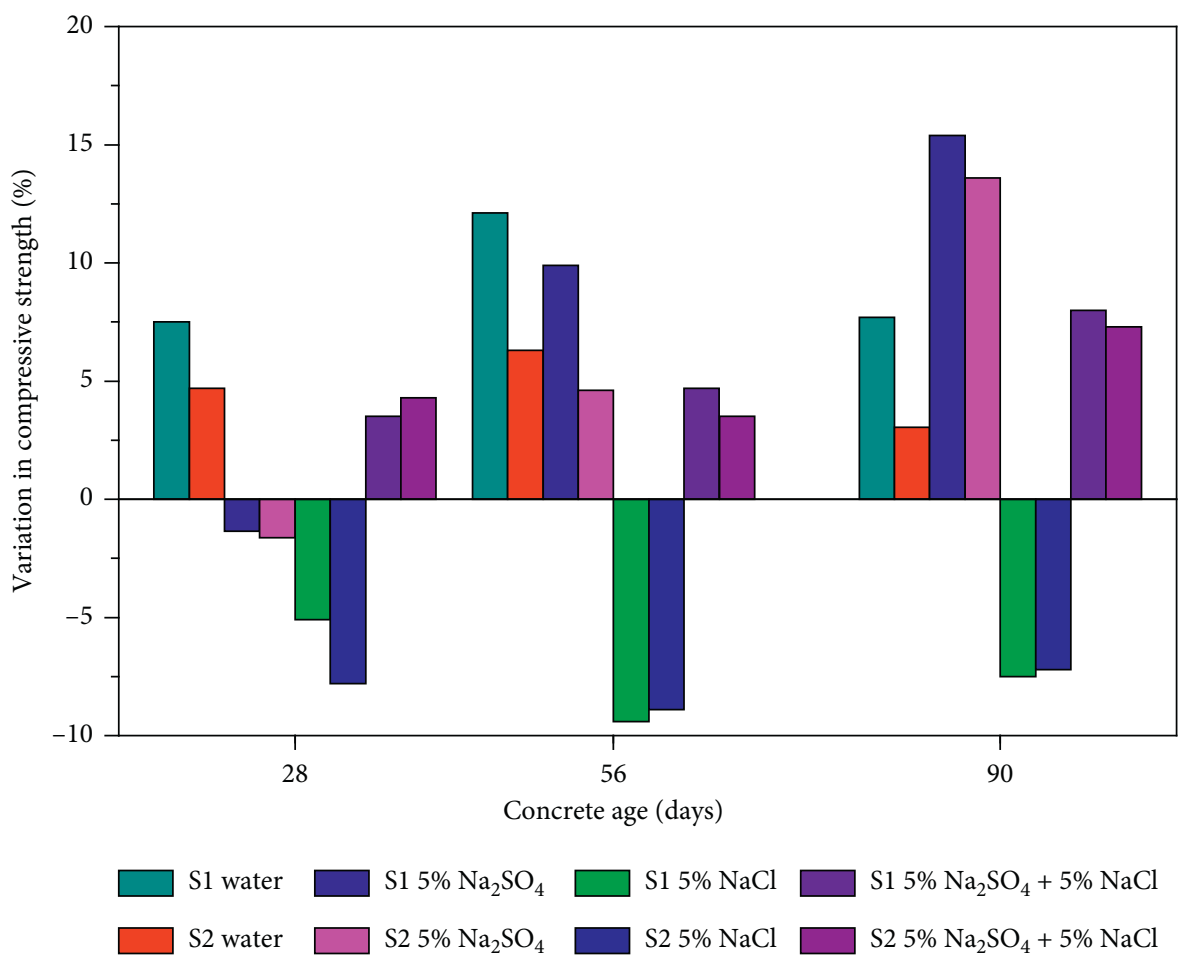

FIgURE 4: Compressive strength variation of CT, S1, and S2 immersed in water, sulphate, and chloride at different concrete ages.

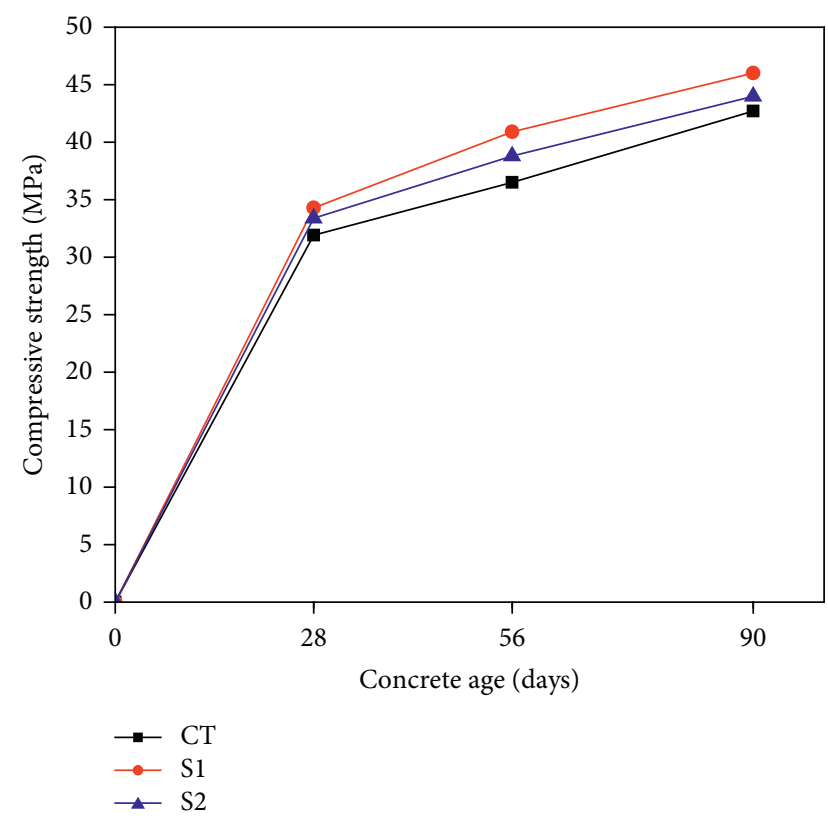

FIGURE 5: Compressive strength of CT, S1, and S2 immersed in potable water.

pumice and scoria, the pozzolanic reaction took place after 28 days and kept on increasing with the concrete age.

The compressive strength of samples immersed in 5\% sodium sulphate curing for different exposure time is presented in Figure 6, and the physical characteristics are presented in Table 6. From Figure 6, concrete samples under the $5 \% \quad \mathrm{Na}_{2} \mathrm{SO}_{4}$ exposure condition show that the

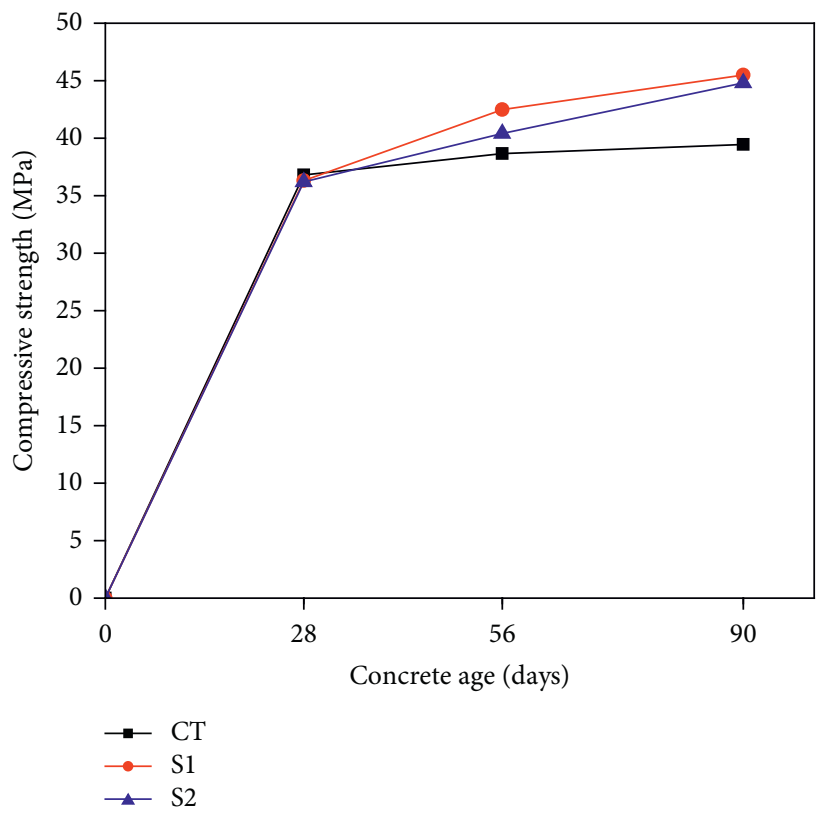

FIGURE 6: Compressive strength of CT, S1, and S2 immersed in the sulphate solution.

performance of concrete samples containing pumice (S1) and scoria (S2) was found to be comparable with concrete without pumice and scoria (CT) at 28 days of immersion. It was noted that concrete samples with and without pumice and scoria after exposure to the sulphate solution have no significant damage caused for the short-term exposure. The compressive strength of S1 was found to be outstanding as 
TABle 6: Physical characteristics of concrete mixes after exposure to the sulphate solution: slight peeling of the surface is visible.

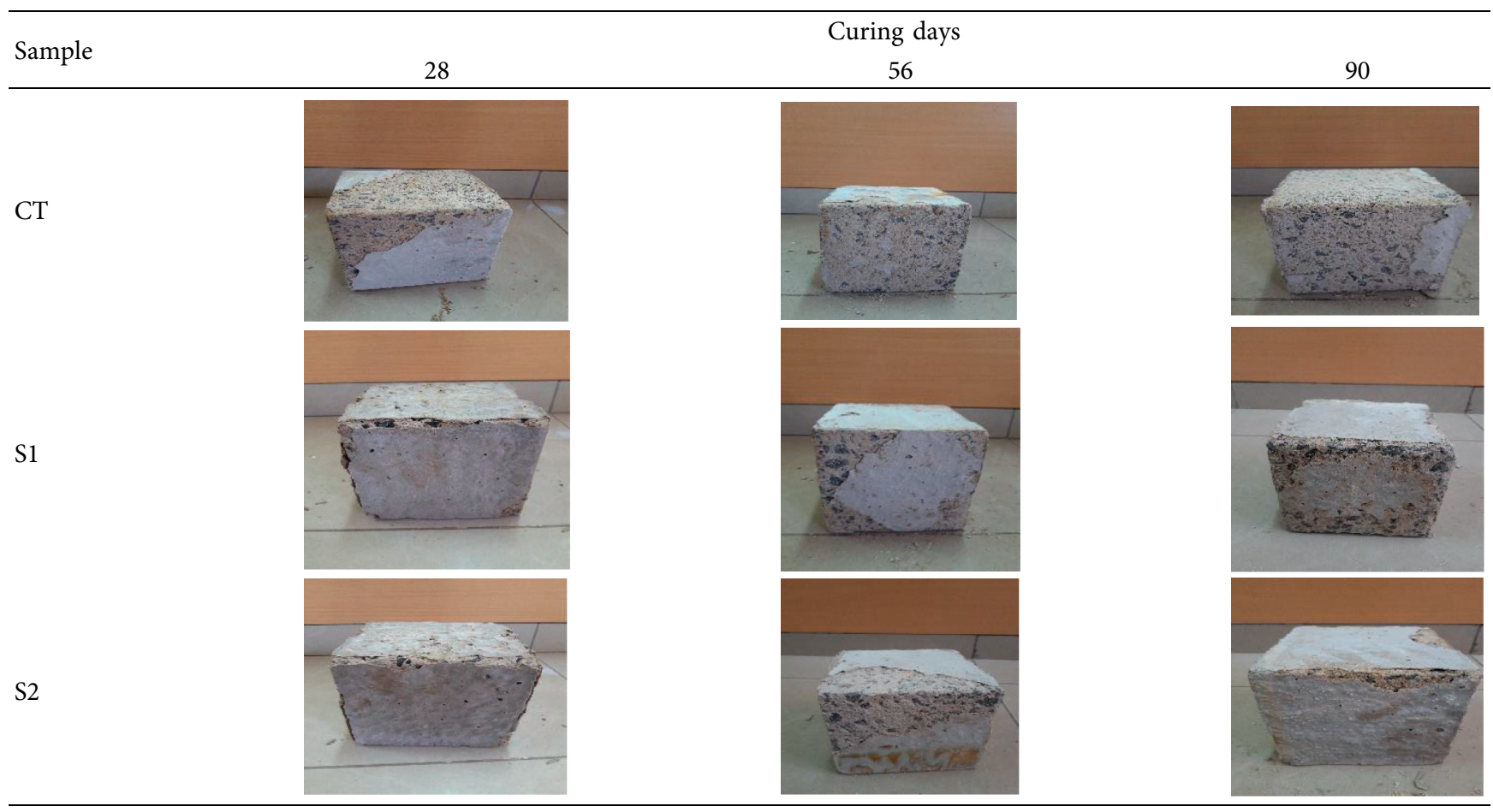

compared to CT by $9.9 \%$ and $15.4 \%$ at 56 and 90 days, respectively. The same trend is observed in $\mathrm{S} 2$ where strength was superior as compared to CT by $4.6 \%$ and $13.6 \%$ at 56 and 90 days, respectively. This concurs with the findings observed by Mangi et al. [1] as they investigated on OPC concrete with coal bottom ashes exposed to the sulphate solution for 90 days exposure time.

Moreover, the findings in the current study concur with the findings reported by Demir et al. [21] where OPC mortar with blast-furnace slag, bottom ash, and fly ash as SMCs was investigated where mortar samples were immersed in the $\mathrm{Na}_{2} \mathrm{SO}_{4}$ solution for 360 days and strength performance of blended mortar was $2 \%$ greater than that of OPC mortar. It was previously declared that samples immersed in lower proportions of $\mathrm{Na}_{2} \mathrm{SO}_{4}(0.27-1.8 \%)$ for 300 days had no significant damage caused on mortar properties.

It was also acknowledged that diffusion of sulphate ions in pores of the concrete accelerates the chemical reaction between cement hydration products. The chemical reaction of $\mathrm{Na}_{2} \mathrm{SO}_{4}$ and sulphate ions with $\mathrm{Ca}$ $(\mathrm{OH})_{2}$ and monosulphate gives gypsum and ettringite (crystal needle) in concrete pores [50, 51]. Addition of pozzolanic materials makes the concrete denser by decreasing the $\mathrm{Ca}(\mathrm{OH})_{2}$ content; at the same time, development of corrosive species becomes hard to grow [52]. Pumice and scoria remove lime liberated during cement hydration and $\mathrm{C}_{3} \mathrm{~A}$ dilution [7]. It was experimentally found that pumice and scoria-blended concrete has better performance and was found to resist the effect of the $\mathrm{Na}_{2} \mathrm{SO}_{4}$ solution. The performance of pumice and scoriablended concrete is attributed by refinement of pore sizes that limits ingress of sulphate ions $[53,54]$.
The compressive strength of samples immersed in 5\% sodium chloride curing for different exposure time is presented in Figure 7, and the physical characteristics are presented in Table 7. The strength development of S1 and S2 was found to be lower than $\mathrm{CT}$ in the $\mathrm{NaCl}$ exposure environment. The same trend has been found in the concrete containing $5 \%$ coal bottom ashes [1] and concrete containing 5\% rice husk ashes [55]. The chloro-aluminate produced in the chloride solution is the reason for strength deterioration, and the deterioration took place by de-calcifications, and the deterioration is notable at later ages $[56,57]$. At the same time, leaching of calcium hydroxide, permeable C-S-H gel formation, and de-calcification effects of $\mathrm{NaCl}$ take place in concrete [55].

It is also known that chlorides promote the leaching of $\mathrm{Ca}(\mathrm{OH})_{2}$ and the formation of porous $\mathrm{C}-\mathrm{S}-\mathrm{H}$ involving complex reactions [58]. Physical appearance of concrete is affected due to disturbance created in the hydration process by the presence of chlorides which affect the pore sizes. From experimental results, $\mathrm{CT}$ in $5 \% \mathrm{NaCl}$ solution gains its strength up to 56 days, and the strength declines after 90 days of immersion time. The performance of S1 and S2 was found to be lower than CT but it was noted that there is continual growth of strength in S1 and S2. It was acknowledged that, under $5 \% \mathrm{NaCl}$, the pozzolanic reaction becomes slow and takes more time to recover [1]. Thus, the performance of S1 and S2 was unsatisfactory under sodium chloride.

The compressive strength of samples immersed in 5\% sodium sulphate and chloride curing for different exposure times is presented in Figure 8, and physical characteristics of concrete mixes after exposure to the sulphate and chloride 


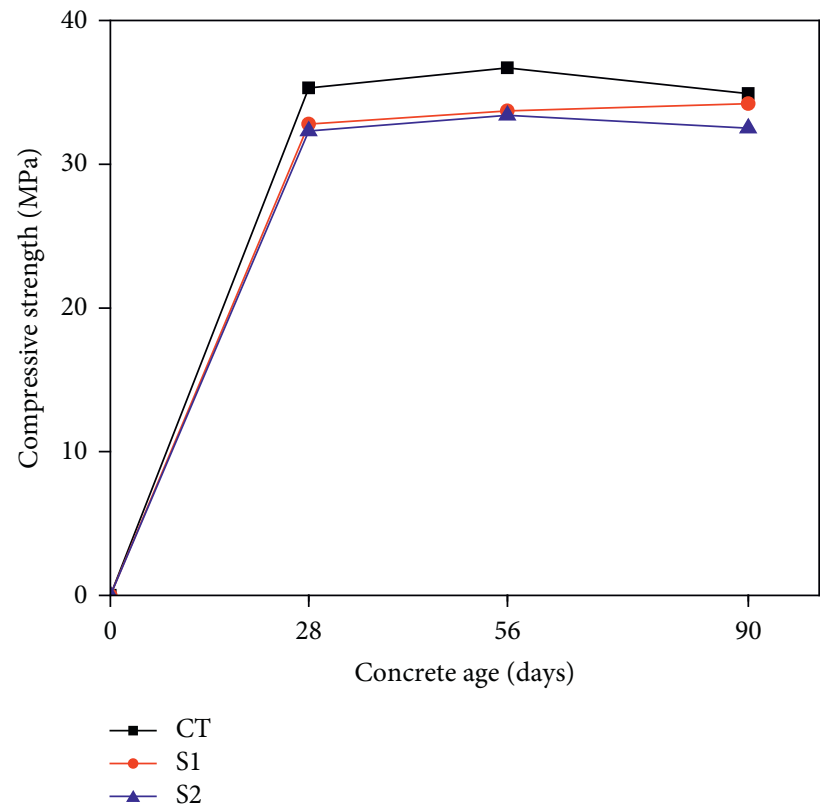

Figure 7: Compressive strength of concrete CT, S1, and S2 immersed in the chloride solution.

TABle 7: Physical characteristics of concrete mixes after exposure to the chloride solution: without significant surface damage.

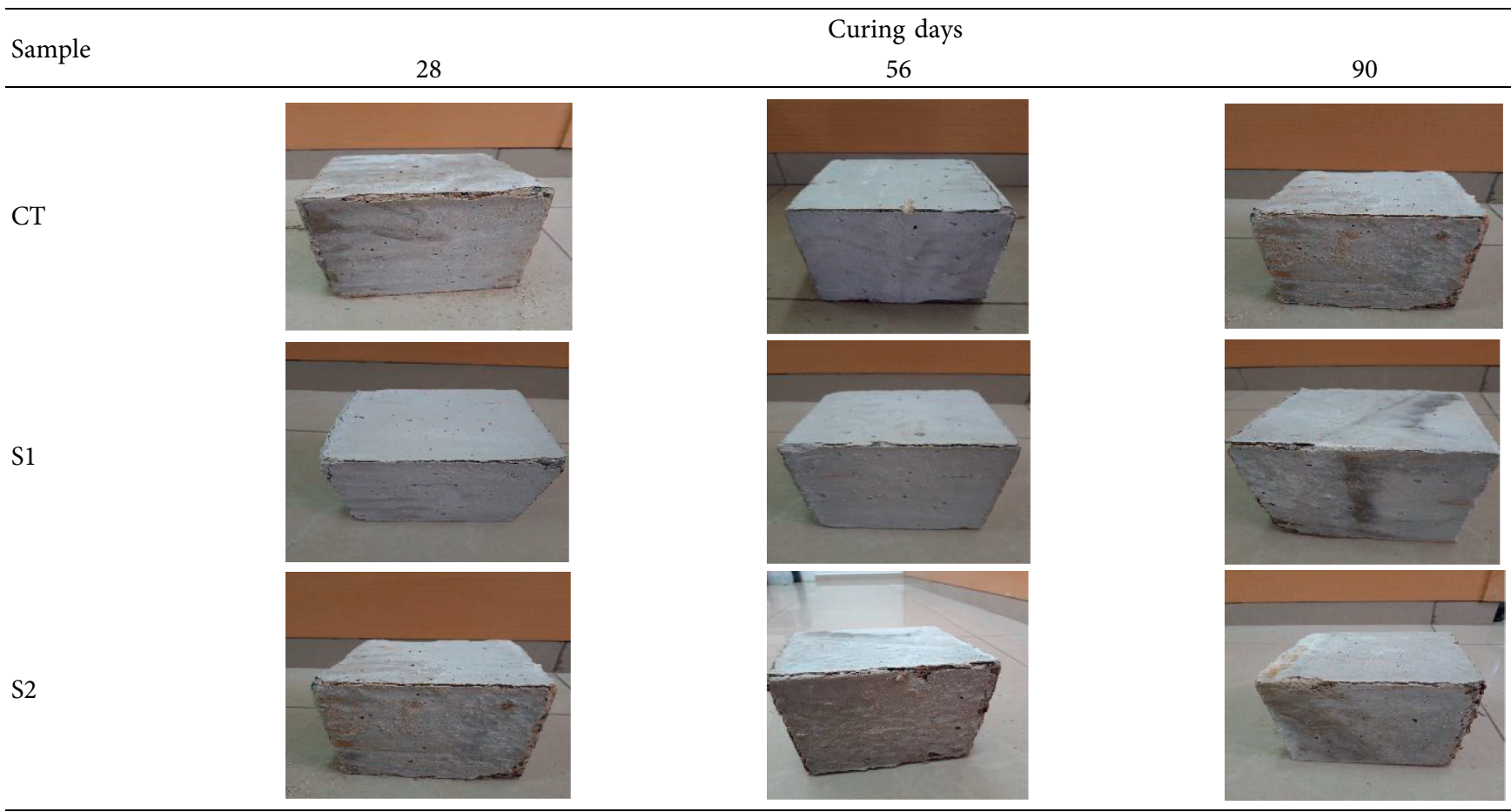

solution are presented in Table 8 . Under the combined exposure of sodium chloride and sulphate, the concrete blended with pumice (S1) and scoria (S2) performed better than the control mix at exposure periods of 28,56 , and 90 days. At 28 days, the performance of S1 and S2 was $4.5 \%$ and $1.3 \%$ greater than $\mathrm{CT}$, respectively. A superior performance is observed at early ages. The compressive strength of S1 concrete is $3.3 \%$ and $8 \%$ greater than the CT at 56 and 90 days, respectively. Its counterpart, S2 has 2.3\% and $7.3 \%$ at 56 and 90 days, respectively.

The decline in compressive strength of CT, S1, and S2 can be explained as follows; both sulphate and chloride bind with $\mathrm{C}_{3} \mathrm{~A}$ to form ettringite, gypsum, and, sometimes, Friedel's salt. However, for Friedel's salt, chlorides' reaction product is not stable under the sodium sulphate solution [59]; as time of immersion is increased, Friedel's 


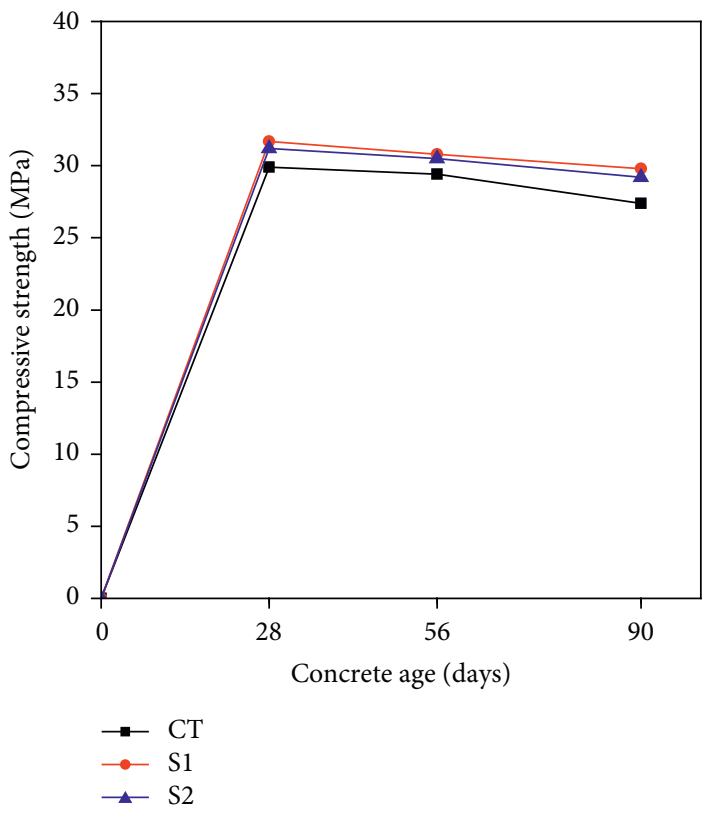

FIgURE 8: Compressive strength of CT, S1, and S2 immersed in the combined solution of sulphate and chloride.

TABLE 8: Physical characteristics of concrete mixes after exposure to sulphate and chloride solution: large peeling of the surface visible.

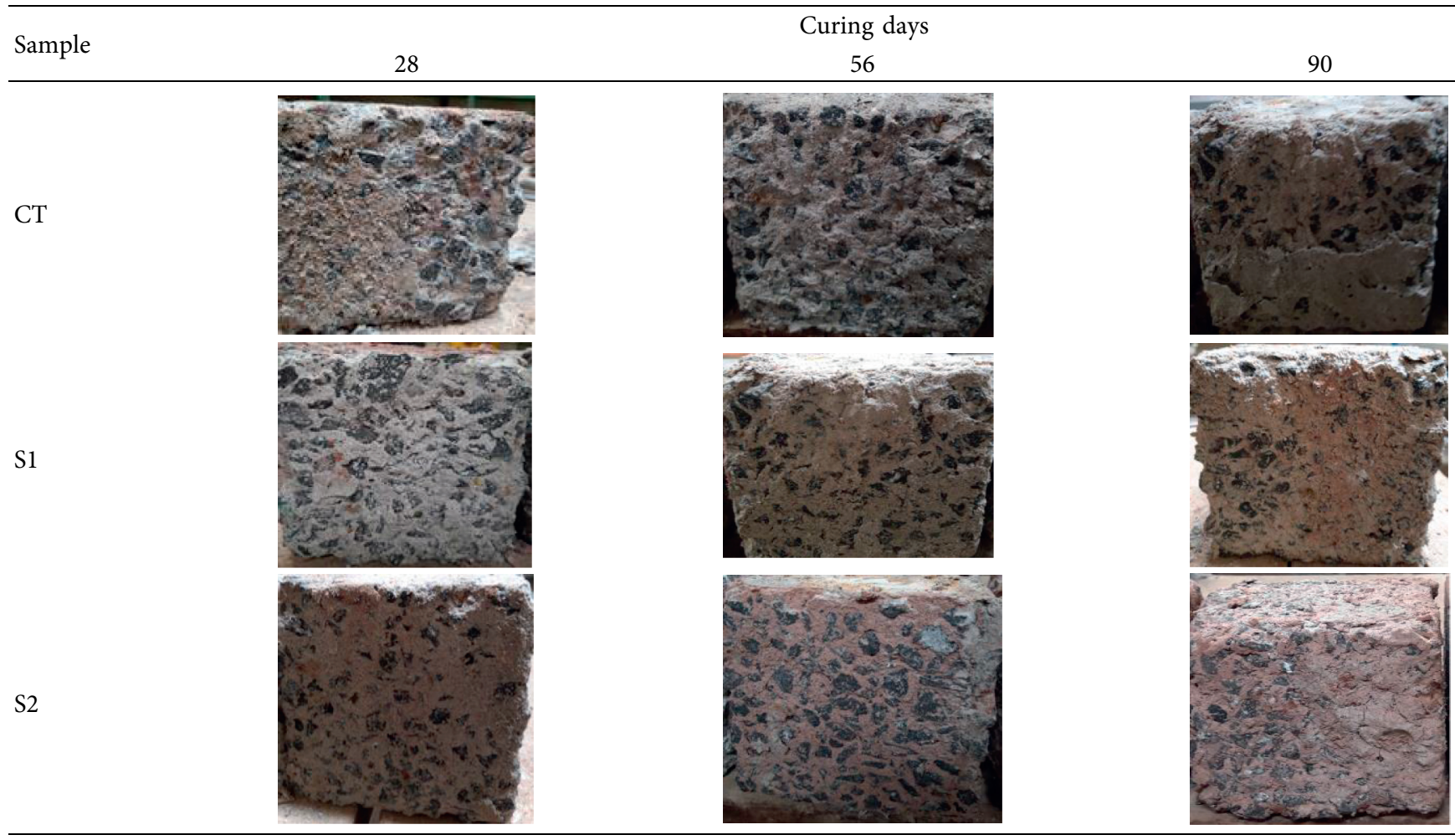

salt will disappear, more ettringite and gypsum will form, and deterioration will occur at later ages. Moreover, ettringite may induce expansion in concrete which may cause a certain cracking in concrete [4]. This cracking leads to increase of chloride penetrability in concrete. The S1 and S2 performance was influenced by the dense microstructure due to the pozzolanic reaction of pumice and scoria so that the penetration of chloride ions becomes less.

3.6. Degree of Damage. The extent of deterioration of concrete specimens immersed in water, sulphate, and chloride was obtained by using equation (1) and graphically 


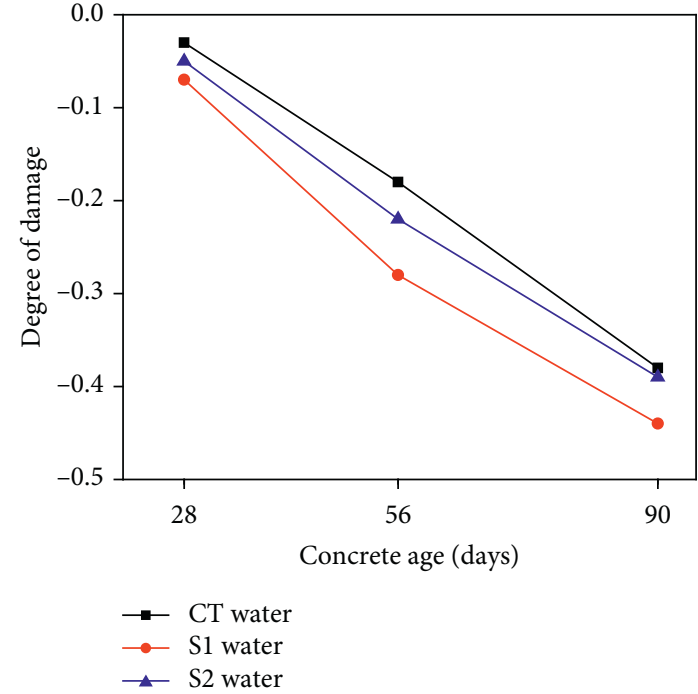

Figure 9: Degree of damage CT, S1, and S2 scoria immersed in water.

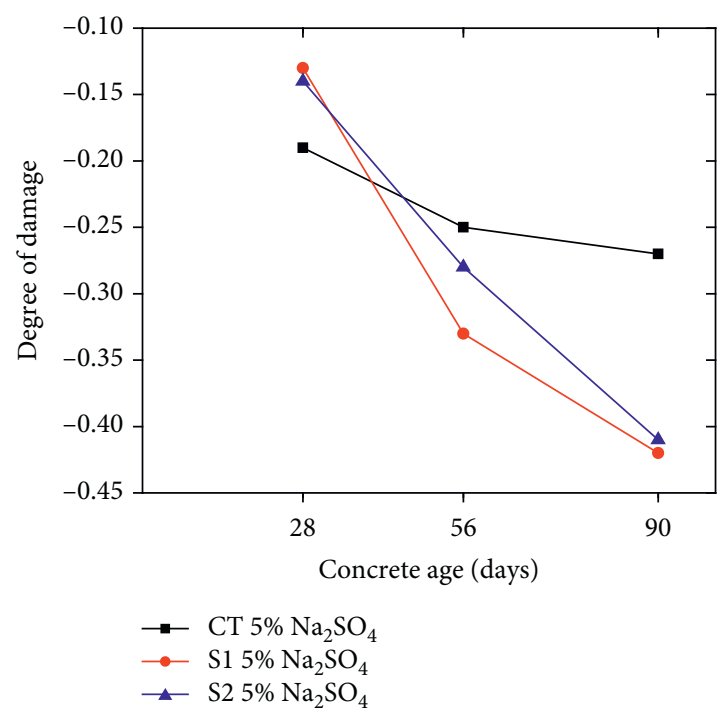

Figure 10: Degree of damage of CT, S1, and S2 immersed in the sulphate solution.

presented in Figures 9-12. The results reveal that the degree of damage of the control mix (CT) is highest at all exposure conditions except for the sodium chloride exposure where the degree of damage is highest. Moreover, the concrete containing pumice (S1) and scoria (S2) has less degree of damage at all exposure conditions except for the sodium chloride exposure.

However, the higher were noticed in CT concrete 0.02, 0.04 , and 0.11 under the combined exposure of sulphate and chloride for 28, 56, and 90 days, respectively. S1 has 0.01 , 0.04 , and 0.08 under the combined exposure of sulphate and chloride for 28, 56, and 90 days, respectively, while S2 has $0.02,0.04$, and 0.7 of 28,56 , and 90 days, respectively. The degree of damage was highest in the control mix (CT) because of the porous structure formed due to chemical

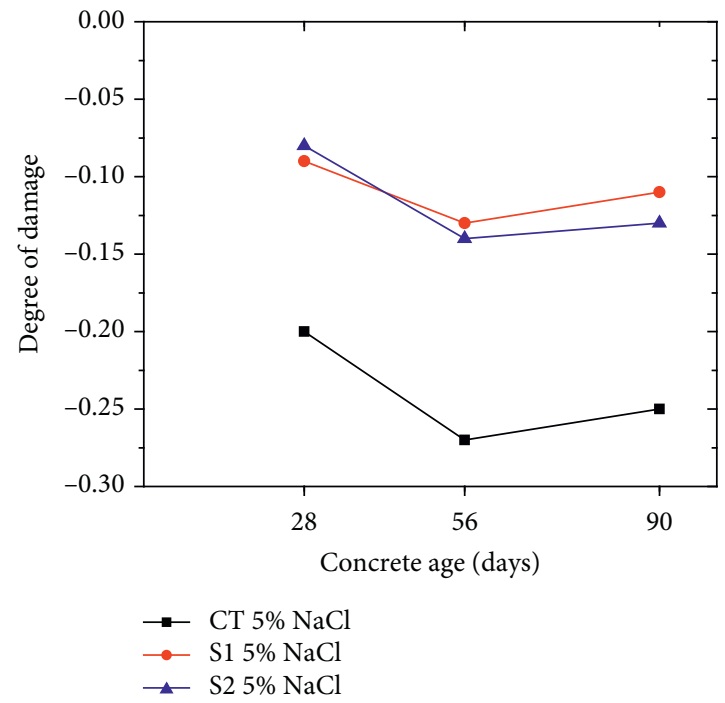

Figure 11: Degree of damage of CT, S1, and S2 immersed in the chloride solution.

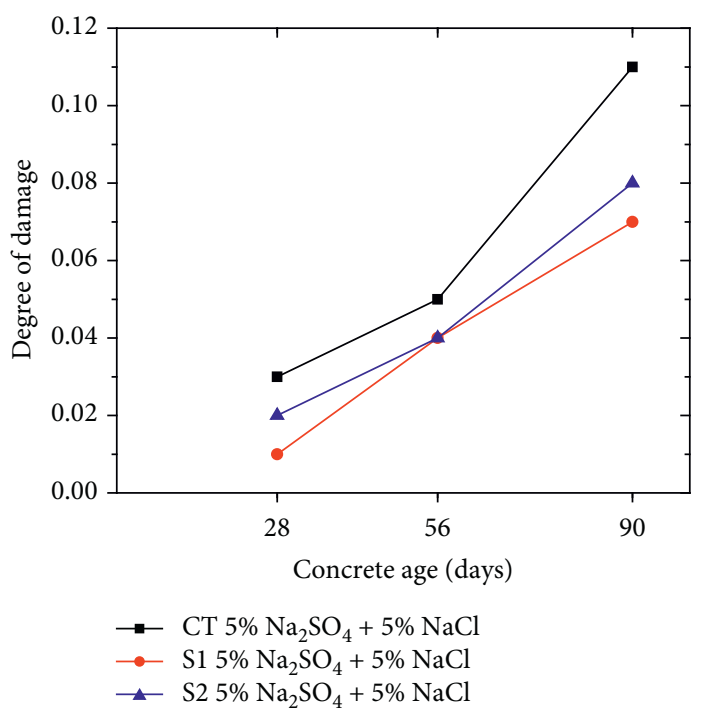

FIgURE 12: Degree of damage of CT, S1, and S2 immersed in the combined sulphate and chloride solution.

corrosion. Due to increase of permeability, the sulphate and chloride solutions can more easily penetrate into interior of concrete; as a result, the porosity is increased, and the effective area is decreased. [3]. The increase in the degree of damage reduces the bearing capacity of concrete structures, and it will reach a degree, and the concrete structure will fail completely [60]. The lower the degree of damage, the higher is the strength and durability of concrete.

\section{Conclusions}

The present study investigated the compressive strength, degree of damage, and physical properties of the cement$\mathrm{NP} / \mathrm{NS}$ blended normal concrete (with design strength of $25 \mathrm{MPa}$ ) subjected to combined sodium sulphate and 
sodium chloride solutions. The blended concrete mixes containing $10 \% \mathrm{NP} / \mathrm{NS}$ showed a greater compressive strength than the control mixes, implying that the inclusion of NP/NS led to improved compressive strength both at the ordinary and aggressive environment. Following are the conclusions drawn on the presented experimental results:

(1) The study indicated the successfulness of pumice and scoria as SCMs to replacement of OPC in concrete under normal and aggressive environments

(2) The concrete S1 (concrete with pumice) and S2 (concrete with scoria) has outperformed concrete CT under sulphate, chloride, and combined sulphate and chloride solutions showing that incorporation of natural pumice and scoria has great potential of alleviating penetration of aggressive salts in concrete structures

(3) The degree of damage of concrete is reduced with the incorporation of natural pumice and scoria, and it is obvious concrete incorporated with natural pumice and scoria has less deterioration caused by aggressive salt solutions

\section{Data Availability}

The data used to support the findings of this study are included within this article.

\section{Conflicts of Interest}

The authors declare that they have no conflicts of interest.

\section{Acknowledgments}

The authors gratefully acknowledge and recognize the contribution of Arusha Technical College for allowing us to have access to their building materials and laboratory to carry out this experimental work. We acknowledge the Tanzania Atomic Energy Commission for allowing us to characterize the pumice and scoria powder. This research work was funded by the African Development Bank (AfDB) Project of Nelson Mandela African Institution of Science and Technology, Grant no. 2100155032816.

\section{References}

[1] S. A. Mangi, M. H. Wan Ibrahim, N. Jamaluddin, M. F. Arshad, and R. Putra Jaya, "Short-term effects of sulphate and chloride on the concrete containing coal bottom ash as supplementary cementitious material," Engineering Science and Technology, an International Journal, vol. 22, no. 2, pp. 515-522, 2019.

[2] A. Hasanbeigi, L. Price, and E. Lin, "Emerging energy-efficiency and $\mathrm{CO}_{2}$ emission-reduction technologies for cement and concrete production: a technical review," Renewable and Sustainable Energy Reviews, vol. 16, no. 8, pp. 6220-6238, 2012.

[3] F. Ming, Y.-S. Deng, and D.-Q. Li, "Mechanical and durability evaluation of concrete with sulfate solution corrosion," $A d$ vances in Materials Science and Engineering, vol. 2016, Article ID 6523878, 7 pages, 2016.
[4] J. I. Kwang, Y. R. Jiang, H. J. Sang, K. L. Myung, S.-W. Yoo, and H. O. Byung, "Durability of concrete under combined exposure conditions of chlorides and sulfates," in Key Engineering MaterialsTrans Tech Publication, Zurich, Switzerland, 2016.

[5] E. Holt, M. Ferreira, H. Kuosa, and M. Leivo, "Performance and durability of concrete under effect of multi-deterioration mechanisms," Journal of the Chinese Ceramic Society, vol. 43, no. 10, pp. 1421-1429, 2015.

[6] J. M. Aldred and A. Castel, "Chloride penetration after field exposure compared with estimates from service life prediction models," in Proceedings of the RILEM International Workshop on Performance-Based Specification and Control of Concrete Durability, Zagreb, Croatia, June 2014.

[7] A. M. Al-Swaidani and S. D. Aliyan, "Effect of adding scoria as cement replacement on durability-related properties," International Journal of Concrete Structures and Materials, vol. 9, no. 2, pp. 241-254, 2015.

[8] S. Barbhuiya and D. Kumala, "Behaviour of a sustainable concrete in acidic environment," Sustainability, vol. 9, no. 9, p. 1556, 2017.

[9] L. Gu, T. Bennett, and P. Visintin, "Sulphuric acid exposure of conventional concrete and alkali-activated concrete: assessment of test methodologies," Construction and Building Materials, vol. 197, pp. 681-692, 2019.

[10] A. M. Zeyad, A. H. Khan, and B. A. Tayeh, "Durability and strength characteristics of high-strength concrete incorporated with volcanic pumice powder and polypropylene fibers," Journal of Materials Research and Technology, vol. 9, no. 1, pp. 806-818, 2020.

[11] J. A. Hartell, A. J. Boyd, and C. C. Ferraro, "Sulfate attack on concrete: effect of partial immersion," Journal of Materials in Civil Engineering, vol. 23, no. 5, pp. 572-579, 2011.

[12] D. Niu, L. Jiang, and Q. Fei, "Deterioration mechanism of sulfate attack on concrete under freeze-thaw cycles," Journal of Wuhan University of Technology-Materials Science and Engineering, vol. 28, no. 6, pp. 1172-1176, 2013.

[13] H. A. Mboya, K. N. Njau, A. L. Mrema, and C. K. King'ondu, "Influence of scoria and pumice on key performance indicators of Portland cement concrete," Construction and Building Materials, vol. 197, pp. 444-453, 2019.

[14] O. Aksoğan, H. Binici, and E. Ortlek, "Durability of concrete made by partial replacement of fine aggregate by colemanite and barite and cement by ashes of corn stalk, wheat straw and sunflower stalk ashes," Construction and Building Materials, vol. 106, pp. 253-263, 2016.

[15] A. Merida and F. Kharchi, "Pozzolan concrete durability on sulphate attack," Procedia Engineering, vol. 114, pp. 832-837, 2015.

[16] K. Onoue, H. Tamai, and H. Suseno, "Shock-absorbing capability of lightweight concrete utilizing volcanic pumice aggregate," Construction and Building Materials, vol. 83, pp. 261-274, 2015.

[17] J. A. Bogas and D. Cunha, "Non-structural lightweight concrete with volcanic scoria aggregates for lightweight fill in building's floors," Construction and Building Materials, vol. 135, pp. 151-163, 2017.

[18] N. M. Chanu and T. K. Devi, "Contribution of rice husk ash to the properties of cement mortar and concrete," International Journal of Engineering Research \& Technology, vol. 2, no. 2, pp. 1-7, 2013.

[19] H. M. Owaid, R. B. Hamid, and M. R. Taha, "A review of sustainable supplementary cementitious materials as an alternative to all-Portland cement mortar and concrete," 
Australian Journal of Basic and Applied Sciences, vol. 6, no. 9, pp. 287-303, 2012.

[20] V. Kannan and K. Ganesan, "Chloride and chemical resistance of self compacting concrete containing rice husk ash and metakaolin," Construction and Building Materials, vol. 51, pp. 225-234, 2014.

[21] İ. Demir, S. Güzelkücük, and Ö. Sevim, "Effects of sulfate on cement mortar with hybrid pozzolan substitution," Engineering Science and Technology, an International Journal, vol. 21, no. 3, pp. 275-283, 2018.

[22] R. Othman, K. Muthusamy, Y. Duraisamy et al., "Evaluation of the sulphate resistance of foamed concrete containing processed spent bleaching earth," European Journal of Environmental and Civil Engineering, vol. 24, pp. 1-16, 2020.

[23] R. P. Jaya, B. H. A. Bakar, M. A. M. Johari, M. H. W. Ibrahim, M. R. Hainin, and D. S. Jayanti, "Strength and microstructure analysis of concrete containing rice husk ash under seawater attack by wetting and drying cycles," Advances in Cement Research, vol. 26, no. 3, pp. 145-154, 2014.

[24] P. N. Lemougna, K.-T. Wang, Q. Tang et al., "Review on the use of volcanic ashes for engineering applications," Resources, Conservation and Recycling, vol. 137, pp. 177-190, 2018.

[25] S. Top and H. Vapur, "Effect of basaltic pumice aggregate addition on the material properties of fly ash based lightweight geopolymer concrete," Journal of Molecular Structure, vol. 1163, pp. 10-17, 2018.

[26] W. H. J. Tchamdjou, S. Grigoletto, F. Michel, L. Courard, M. L. Abidi, and T. Cherradi, "An investigation on the use of coarse volcanic scoria as sand in Portland cement mortar," Case Studies in Construction Materials, vol. 7, pp. 191-206, 2017.

[27] W. H. J. Tchamdjou, M. L. Abidi, T. Cherradi, and A. P. D. Luiz, "Mechanical properties of lightweight aggregates concrete made with cameroonian volcanic scoria: destructive and non-destructive characterization," Journal of Building Engineering, vol. 16, pp. 134-145, 2018.

[28] CEN, Cement Part 1: Composition, Specifications and Conformity Criteria for Common Cements, European Committee for Standardization Brussels, Brussels, Belgium, 2011.

[29] BS 410, "BS 410:1986 Specification for test sieves," British Standard, vol. 1, pp. 10-13, 1986.

[30] SS-EN 196-6, Methods of Testing Cement-Part 6: Determination of Fineness, National Standard Authority of Ireland, Dublin, Ireland, 2010.

[31] SS-EN 197-1, Cement-Part 1: Composition, Specification and Conformity Criteria for Common Cements, National Standard Authority of Ireland, Dublin, Ireland, 2011.

[32] ASTM D854, Standard Test for Specific Gravity of Soil Solids by Water Pycnometer, ASTM International, West Conshohocken, PA, USA, 2003.

[33] C127-01, A Standard Test Method for Density, Relative Density (Specific Gravity), and Absorption of Coarse Aggregate, ASTM International, West Conshohocken, PA, USA, 2001.

[34] ASTM, A Standard Test Method for Density, Relative Density (Specific Gravity), and Absorption of Fine Aggregate, ASTM International, West Conshohocken, PA, USA, 2007.

[35] BS EN 933-1, Tests for Geometrical Properties of Aggregates Determination of Particle Size Distribution, Sieving Method; British Standards Institution, London, UK, 2012.

[36] PD 6682-1:, Aggregates-Part 1: Aggregates for concrete-Guidance on thenuse of BS EN 12620, Vol. 3, British Standards Institution, Lonndon, UK, 2003.

[37] BS EN 12620, Aggregates for Concrete, British Standards Institution, Lonndon, UK, 2002.
[38] M. L. Gambhir, Concrete Technology: Theory and Practice, Tata McGraw-Hill Education, 2013.

[39] BS 1881-116, Testing Concrete-Part 116: Method for Determination of Compressive Strength of Concrete Cubes, British Standards Institution, Lonndon, UK, 1983.

[40] BS EN 12390-2, Testing Hardened Concrete-Part 2: Making and Curing Specimens for Strength Tests, National Standard Authority of Ireland, Dublin, Ireland, 2003.

[41] BS EN 206, Concrete-Specification, Performance, Production and Conformity, British Standards Institution, Lonndon, UK, 2014.

[42] BS EN 12390-3, Testing hardened concrete. Compressive Strength of Test Specimens, British Standards Institution, Lonndon, UK, 2019.

[43] ASTM C618, Standard Specification for Coal Fly Ash and Raw or Calcined Natural Pozzolan for Use in Concrete, ASTM International, West Conshohocken, PA, USA, 2005.

[44] ASTM C143, Standard Test Method for Slump of HydraulicCement Concrete, ASTM International, West Conshohocken, PA, USA, 2015.

[45] D. A. Adesanya and A. A. Raheem, "A study of the workability and compressive strength characteristics of corn cob ash blended cement concrete," Construction and Building Materials, vol. 23, no. 1, pp. 311-317, 2009.

[46] H. Xu, Y.-X. Zhao, L. Cui, and B. Xu, "Sulphate attack resistance of high-performance concrete under compressive loading," Journal of Zhejiang University SCIENCE A, vol. 14, no. 7, pp. 459-468, 2013.

[47] M. Maes and N. De Belie, "Resistance of concrete and mortar against combined attack of chloride and sodium sulphate," Cement and Concrete Composites, vol. 53, pp. 59-72, 2014.

[48] R. Jaya, B. Badorul, J. Megat, and I. Mohd, "Strength and permeability properties of concrete containing rice husk ash with different grinding time," Open Engineering, vol. 1, no. 1, pp. 103-112, 2011.

[49] P. Ramadhansyah, B. Badorul, J. Megat, and I. Mohd, "Engineering properties of normal concrete grade 40 containing rice husk ash at different grinding times," International Journal of Technology, vol. 2, no. 1, pp. 10-19, 2011.

[50] F. Aköz, F. Türker, S. Koral, and N. Yüzer, "Effects of raised temperature of sulfate solutions on the sulfate resistance of mortars with and without silica fume," Cement and Concrete Research, vol. 29, no. 4, pp. 537-544, 1999.

[51] I. Saribas and O. Cakir, "Short-term effects of sodium sulfate and sodium chloride solutions on the strength and durability properties of hardened mortars," European Journal of Science and Technology, vol. 6, no. 10, pp. 38-47, 2017.

[52] Portland Cement Association, Ettringite Formation and the Performance of Concrete, Portland Cement Association, New York City, NY, USA, 2001.

[53] J. N. Y. Djobo, A. Elimbi, H. T. Kouama, and S. Kumar, "Mechanical properties and durability of volcanic ash based geopolymer mortars," Construction and Building Materials, vol. 124, pp. 606-614, 2016.

[54] M. F. Granata, "Pumice powder as filler of self-compacting concrete," Construction and Building Materials, vol. 96, pp. 581-590, 2015.

[55] A. Abalaka and A. Babalaga, "Effects of sodium chloride solutions on compressive strength development of concrete containing rice husk ash," ATBU Journal of Environmental Technology, vol. 4, no. 1, pp. 33-40, 2011.

[56] Q. Yuan, C. Shi, G. De Schutter, K. Audenaert, and D. Deng, "Chloride binding of cement-based materials subjected to 
external chloride environment-a review," Construction and Building Materials, vol. 23, no. 1, pp. 1-13, 2009.

[57] M. Santhanam, M. Cohen, and J. Olek, "Differentiating seawater and groundwater sulfate attack in Portland cement mortars," Cement and Concrete Research, vol. 36, no. 12, pp. 2132-2137, 2006.

[58] H. Lee, "Effects of various deicing chemicals on pavement concrete deterioration," in Proceedings of the Mid-Continent Transportation Symposium Proceedings, Iowa State University, Ames, IA, USA, August 2000.

[59] P. W. Brown and S. Badger, "The distributions of bound sulfates and chlorides in concrete subjected to mixed $\mathrm{NaCl}$, $\mathrm{MgSO}_{4}, \mathrm{Na}_{2} \mathrm{SO}_{4}$ attack," Cement and Concrete Research, vol. 30, no. 10, pp. 1535-1542, 2000.

[60] P. S. Ramadhansyah, M. Z. M. Salwa, B. H. Baker, and M. A. M. Johan, "Properties of concrete containing rice husk ash under sodium chloride subjected to wetting and drying," Procedia Engineering, vol. 50, pp. 305-313, 2012. 